\title{
Drugs Elevating Extracellular Adenosine Administered in vivo Induce Serum Colony-Stimulating Activity and Interleukin-6 in Mice
}

\author{
L. WEITEROVÁ ${ }^{1}$, M. HOFER ${ }^{1}$, M. POSPÍŠIL ${ }^{1}$, V. ZNOJIL ${ }^{2}$, D. ŠTREITOVÁ ${ }^{1}$ \\ ${ }^{1}$ Institute of Biophysics, Academy of Sciences of the Czech Republic, Brno, Czech Republic and \\ ${ }^{2}$ Institute of Pathological Physiology, Medical Faculty, Masaryk University, Brno, Czech Republic
}

Received May 5, 2006

Accepted July 10, 2006

On-line available August 22, 2006

\begin{abstract}
Summary
Our previous studies have shown that the combined administration of drugs elevating extracellular adenosine, i.e. dipyridamole (DP) and adenosine monophosphate (AMP), enhances murine hematopoiesis and potentiates the action of granulocyte colony-stimulating factor (G-CSF). In this study, colony-stimulating activity (CSA) of blood serum of mice treated with DP+AMP, G-CSF or all these drugs in combination, i.e. the ability of the sera to stimulate the growth of GM-CFC colonies, was assayed in vitro. Furthermore, the concentration of GM-CSF and IL-6 in the sera was determined. Administration of DP+AMP was found to enhance significantly serum CSA at all time intervals of serum sampling including $24 \mathrm{~h}$ after the last injection of the tested drugs. Additive effects of DP+AMP and G-CSF on serum CSA were noted at early intervals after administration of the drugs. Furthermore, IL-6 levels were significantly elevated in the sera of mice which were administered DP+AMP either alone or in combination with G-CSF. Our results show that the effects of DP+AMP are indirect, mediated through the induction of some cytokine(s) and/or growth factor(s) and that extracellular adenosine can act in cooperation with G-CSF. These findings contribute to the further elucidation of the role of adenosine in hematopoiesis.
\end{abstract}

\section{Key words}

Extracellular adenosine $\bullet$ Granulopoiesis $\bullet$ G-CSF $\bullet$ Serum colony-stimulating activity $\bullet$ GM-CFC $\bullet$ IL-6

\section{Introduction}

Adenosine and adenine nucleotides represent a universal system of intracellular signals that are capable of modulating a variety of cell functions including cell growth, development and maturation (Abbracchio 1996, Schulte and Fredholm 2003). There is evidence that adenosine and synthetic analogues of adenosine can act as potent regulators of the proliferation of normal and tumor cells from various sources (Ohana et al. 2001, Mujoomdar et al. 2003, Kronenwett et al. 2005) or may trigger apoptosis in cancer cells under certain circumstances (Kohno et al. 1996, Barry and Lind 2000). Studies performed in our laboratories have shown that adenosine signaling can also participate in the control of hematopoiesis. It has been demonstrated that elevation of extracellular adenosine under in vivo conditions induced by the combined administration of dipyridamole (DP) 
and adenosine monophosphate (AMP) enhances hematopoiesis in normal and myelosuppressed mice and synergizes with the effects of granulocyte colonystimulating factor (G-CSF) (Hofer et al. 1997, 1999, 2001, 2002, Pospíśil et al. 1995, 1998, Weiterová et al. 2000). It has been noted that these hematopoiesisstimulating effects are pleiotropic and result from enhanced cycling of progenitor cells (Pospíšil et al. 2001). Adenosine has been shown to potentiate stimulatory effects of certain hematopoietic growth factors also in an in vitro study (Hofer et al. 2006). The possibility to utilize adenosine receptor signaling in enhancing hematopoiesis has been confirmed by experiments of Fishman et al. (2000) and Bar-Yehuda et al. (2002) demonstrating the curative effects of adenosine and an adenosine $\mathrm{A} 3$ receptor agonist on hematopoiesis in cyclophosphamide-treated mice.

The extracellular regulatory actions of adenosine are mediated via four subtypes of $G$ protein-coupled receptors distinguished as A1, A2A, A2B and A3 (Klotz 2000, Fredholm et al. 2001). Adenosine signaling observed in the above-mentioned studies modulates the growth of different populations of progenitor cells by activating different adenosine receptor subtypes. Besides directly affecting target cells via a receptor-dependent mechanism, adenosine signaling could also modulate hematopoiesis indirectly through its action on the regulatory network. It has been reported that activation of adenosine receptors modifies the production of secondary mediators such as cytokines and growth factors in an astrocytoma cell line, lipopolysaccharide-stimulated endothelial cells, monocytes and macrophages (Bouma et al. 1994, 1996, McWhinney et al. 1996, Jacobson 1998). In studies using selective agonists of adenosine receptors, modifications of cytokine release in vivo have been demonstrated (Hasko et al. 2000, Bar-Yehuda et al. 2002, Forrest et al. 2005). Moreover, Fishman et al. (2000) demonstrated the capability of the agonists of A1 and A3 adenosine receptors to induce G-CSF production, which led to hematopoiesis-stimulating effects.

Hematopoiesis is regulated by a complex interplay between the bone marrow hematopoietic and microenvironmental cells. The production of cytokines plays a critical role in this process. The experiments with many types of agents have demonstrated that hematopoiesis-stimulating effects of these drugs positively correlate with the up-regulation of cytokine production such as granulocyte colony-stimulating factor, granulocyte-macrophage colony-stimulating factor (GM$\mathrm{CSF}$ ), erythropoietin, thrombopoietin, stem cell factor, interleukin-1, interleukin-3 and interleukin-6 (IL-6) (Halaas et al. 1997, Son et al. 2003, Lebedev et al. 2004, Talmadge et al. 2004, Hanley et al. 2005). The involvement of adhesion molecules, which are expressed on hematopoietic stem/progenitor cells and cells of the bone marrow microenvironment, in the regulation of production GM-CSF and IL-6 has been described (Khaldoyanidi et al. 2002).

It has previously been reported in our laboratory that the addition of sera of mice administered various immunomodulatory agents to cultures of normal murine bone marrow cells can potentiate proliferation of hematopoietic progenitor cells for granulocytes and macrophages (GM-CFC) in vitro. These findings have added new information about the ways by which these immunomodulators exert their hematopoiesis-stimulating activity (Vacek et al. 2000, 2001). To obtain further information on the role of adenosine receptor signaling in hematopoiesis, we assessed the ability of sera of mice treated with drugs elevating extracellular adenosine given alone or in combination with G-CSF to stimulate proliferation of GM-CFC in vitro. It is known that colony-stimulating activity of sera is mediated by induced production of secondary substances stimulating the GMCFC proliferation (Fedoročko et al. 2002). To obtain some data on the mechanisms through which the sera of mice treated with drugs elevating extracellular adenosine exert their colony-stimulating activity, the production of GM-CSF and IL-6 in the sera has been determined by the ELISA method.

\section{Materials and Methods}

Animals

B10CBAF1 male mice or ICR1 female mice aged 3 months and weighing an average $30 \mathrm{~g}$ were obtained from the breeding facility of the Medical Faculty, Masaryk University, Brno, Czech Republic. The mice were kept under controlled conditions; standardized pelleted diet and HCl-treated tap water were available ad libitum. The use and treatment of animals followed the European Community Guidelines as accepted principles for the use of experimental animals. The experiments were performed with the approval of the Institute Ethics Committee.

\section{Drugs and their administration}

Based on our earlier experience (Pospíšil et al. 1995, 1998, Hofer et al. 1999), elevation of extracellular adenosine was induced by the combined administration of 
dipyridamole (DP), a drug inhibiting the cellular uptake of adenosine, and AMP, serving as a source of exogenous adenosine. DP (Sigma-Aldrich, St. Louis, MO) was dissolved in $0.4 \%$ tartaric acid and injected subcutaneously at a dose of $2 \mathrm{mg}$ per mouse in a volume of $0.4 \mathrm{ml}$. AMP from yeast (Sigma-Aldrich) was diluted with saline and given intraperitoneally at a dose of $5 \mathrm{mg}$ free acid per mouse in a volume of $0.2 \mathrm{ml} 20 \mathrm{~min}$ after the administration of DP. In the combination treatment, recombinant human G-CSF (Neupogen, F. HoffmanLaRoche Ltd., Switzerland) was dissolved in $5 \%$ glucose and injected subcutaneously at a dose of $1.5 \mu \mathrm{g}$ per mouse in a volume of $0.1 \mathrm{ml} 30 \mathrm{~min}$ after AMP. Respective vehicles were injected to the controls. In the repeated administration of drugs, 24-h intervals were used. DP+AMP, G-CSF, or all these drugs in a combination or respective vehicles were administered either singly or repeatedly in a 4-day treatment regimen.

\section{Preparation of sera}

One, $3,5,12$ or $24 \mathrm{~h}$ after a single injection or the last one, peripheral blood samples were collected by cardiac puncture and sera of 5 mice were pooled in each experimental group. After two hours of blood incubation at room temperature and centrifugation, sera were removed and stored at $<20{ }^{\circ} \mathrm{C}$ until in vitro testing. Sera of animals in all experimental groups were added to the cultures of normal bone marrow cells, in vitro clonogenic assays for GM-CFC were performed and the colony stimulating activities of blood serum were evaluated.

In experiments monitoring the production of GM-CSF and IL-6 in sera, peripheral blood from each mouse taken 3 or $5 \mathrm{~h}$ after a single injection of the tested drugs was placed into individual tubes. Sera were prepared and stored as described above until the implementation of ELISA assays.

\section{Assessment of GM-CFC numbers}

For GM-CFC determination, femoral bone marrow cells from untreated mice were withdrawn by flushing the femoral bone with Iscove's modification of Dulbecco's medium (IMDM) and counted with a Coulter counter (Model ZF; Coulter Electronics Ltd, Luton, Beds, UK). The cells were then plated in triplicates in a semisolid environment created by a plasma clot (Hofer et al. 2005, Vacek et al. 1990, Pospíšil et al. 2004) containing IMDM plus $20 \%$ fetal bovine serum, $1 \%$ conditioned medium containing recombinant murine interleukin-3 (rmIL-3) produced by a myeloma cell line (purchased from the Institute of Hematology and Blood Transfusion, Prague, Czech Republic), $10 \%$ citrate bovine plasma, and $\mathrm{CaCl}_{2}$ at a concentration of $1.5 \mathrm{mg} / \mathrm{ml}$. Colonies of at least 50 cells were counted after 7 days of incubation in $37^{\circ} \mathrm{C}$ humidified environment containing $5 \% \mathrm{CO}_{2}$. The experiments were repeated six times.

Colony stimulating activity (CSA) was defined as the ability of the sera of drug-treated mice to stimulate the growth of GM-CFC colonies, induced by a suboptimum concentration of rmIL-3. The dose of rmIL-3 was adjusted to a value that yields $30 \%$ of maximum numbers of colonies in dose-dependent curve.

\section{ELISA assays}

Concentrations of murine IL-6 and murine GM-CSF in the sera were measured using commercially available ELISA kits (R\&D Systems, Inc, Minneapolis, USA). The assay had sensitivities of $3.1 \mathrm{pg} / \mathrm{ml}$ for IL-6 and $1 \mathrm{pg} / \mathrm{ml}$ for GM-CSF. The experiments were repeated twice.

\section{Statistics}

The results are presented as means \pm S.E.M. The experimental data were subjected to Kruskal-Wallis analysis of variance followed by detailed nonparametric analysis between groups or were evaluated by the t-test with Holms correction for multiple comparisons. The significance levels were set as $\mathrm{P}<0.05$ and $\mathrm{P}<0.01$.

\section{Results}

Effects of single administration of $D P+A M P, G-C S F$ or combination of all the drugs on serum CSA

As statistically significant differences among the colony-stimulating activity (CSA) of sera of intact controls and controls injected by respective vehicles were not demonstrated, all control groups were linked together into one control group. In comparison with the controls, sera of mice given a single injection of the drugs elevating adenosine (DP+AMP) were found to have significantly enhanced CSA in all of the tested time intervals after administration of the drugs $(1,3,5,12$, and 24 hours). The same was true for sera of mice administered G-CSF alone or given the combination of all the three drugs (Fig. 1A). As follows from Figure 1A, very similar results were obtained in the time intervals of 1,3 , and $5 \mathrm{~h}$ (denoted further as early time intervals); a considerable similarity was observed also in the time 

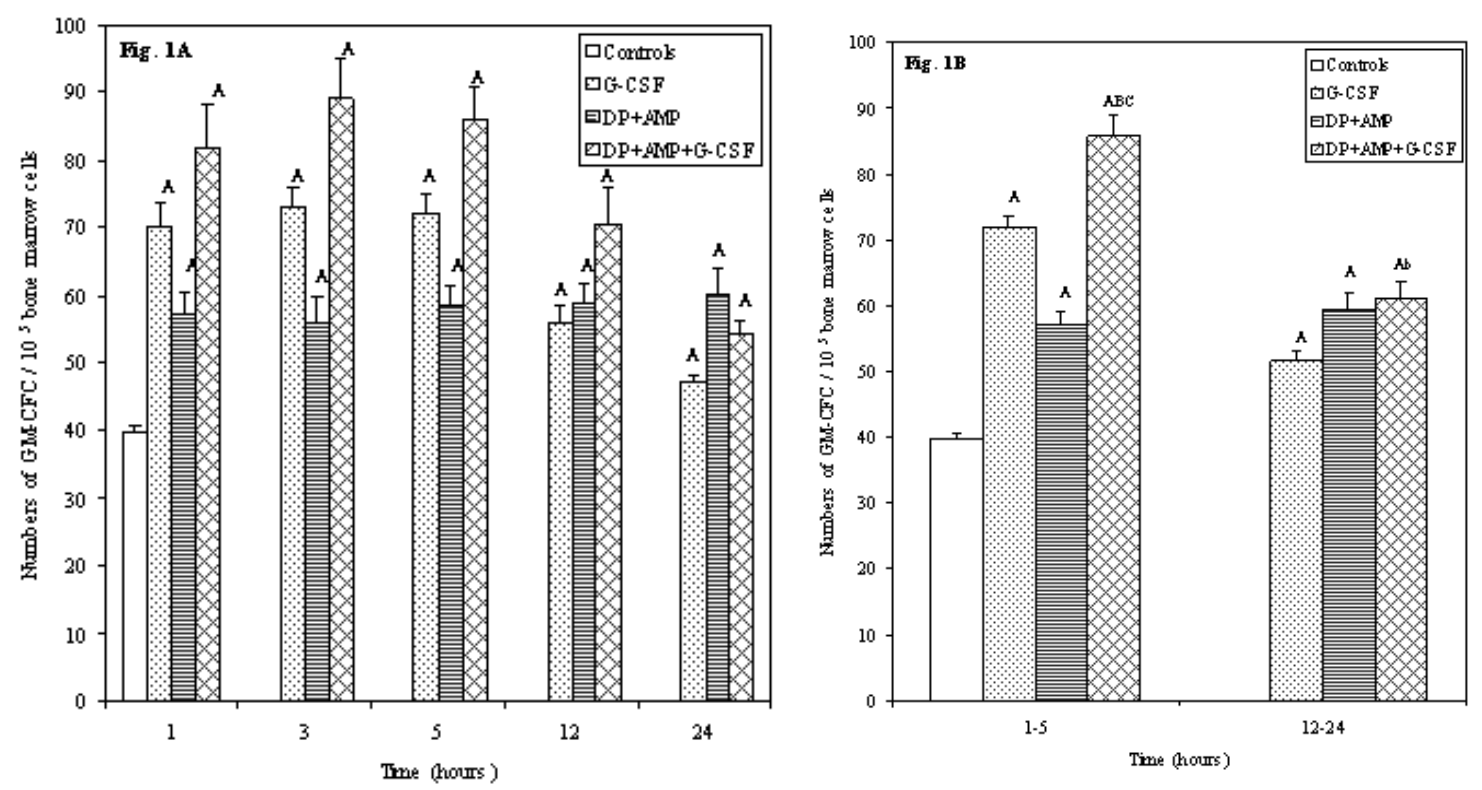

Fig. 1A, B. Numbers of GM-CFC per $10^{5}$ bone marrow cells in cultures treated with serum of mice administered G-CSF, DP+AMP or a combination of DP+AMP+G-CSF in a single dose. Data are given as means \pm S.E.M. Controls - sera of control mice. Time - time-interval between the last injection of the drugs and serum sampling (Fig. $1 \mathrm{~A}-$ values in individual time intervals, Fig. $1 \mathrm{~B}-$ values in grouped early and late intervals). Statistical significance: $A, p<0.01$, in comparison with controls. B and $b, p<0.01$ and $p<0.05$, respectively, in comparison with the cultures treated with serum of mice administered G-CSF alone. $C, p<0.01$, in comparison with the cultures treated with serum of mice administered DP+AMP.

intervals of 12 and $24 \mathrm{~h}$ (denoted further as late time intervals). Since appropriate statistical approaches revealed that it was possible to put together data from the early time intervals, as well as those from the late time intervals, the data were grouped in this way, and further statistical testing was performed in these newly formed groups of data from early and late time intervals. Figure 1B shows that in the early time intervals the CSA of sera of mice given a combination of $\mathrm{DP}+\mathrm{AMP}+\mathrm{G}-\mathrm{CSF}$ was significantly higher in comparison with the CSA of control sera as well as with that of sera of mice given DP+AMP alone. In the late time intervals there was no significant difference between CSA of sera of mice given the drugs elevating adenosine (DP+AMP) alone and that of sera of mice administered the $\mathrm{DP}+\mathrm{AMP}+\mathrm{G}-\mathrm{CSF}$ combination (Fig. 1B).

Effects of repeated administration of DP+AMP, G-CSF or combination of all the three drugs on serum CSA

When the drugs were administered repeatedly in a 4-day regimen and sera were taken at the intervals of 1 , $3,5,12$ and $24 \mathrm{~h}$ after the last injection of the drugs, the results obtained were very similar to those found at the same time intervals after a single injection of the drugs (Fig. 2A). The arrangement of the data made it possible to group them in the same way as performed with those obtained after a single drug injection; after putting the data together into the data groups from early and late time intervals, again a similar picture, including the lack of a statistically significant difference was obtained (Fig. 2B) between the value of the DP+AMP group and that of the $\mathrm{DP}+\mathrm{AMP}+\mathrm{G}-\mathrm{CSF}$ group in the late time intervals.

The detection of IL-6 and GM-CSF in the sera of experimental animals

IL-6 and GM-CSF levels were determined in the sera of mice administered DP+AMP alone, G-CSF alone, or the combination of $\mathrm{DP}+\mathrm{AMP}+\mathrm{G}-\mathrm{CSF}$ and assessed in the time intervals of 3 or $5 \mathrm{~h}$ after the injection. The results of IL-6 are summarized in Figure 3. A significant elevation of the IL- 6 level was detected neither in the sera of control mice nor in those of mice given G-CSF alone. As shown in Figure 3, IL-6 levels were significantly elevated in the sera of mice which were administered DP+AMP either alone or in combination with G-CSF. No statistically significant differences were found between IL-6 levels in the sera of mice given DP+AMP and those of mice administered $\mathrm{DP}+\mathrm{AMP}+\mathrm{G}-\mathrm{CSF}$ in combination. No detectable GM-CSF levels were determined in the sera of control mice as well as in the sera of mice administered the tested drugs (data not shown). 

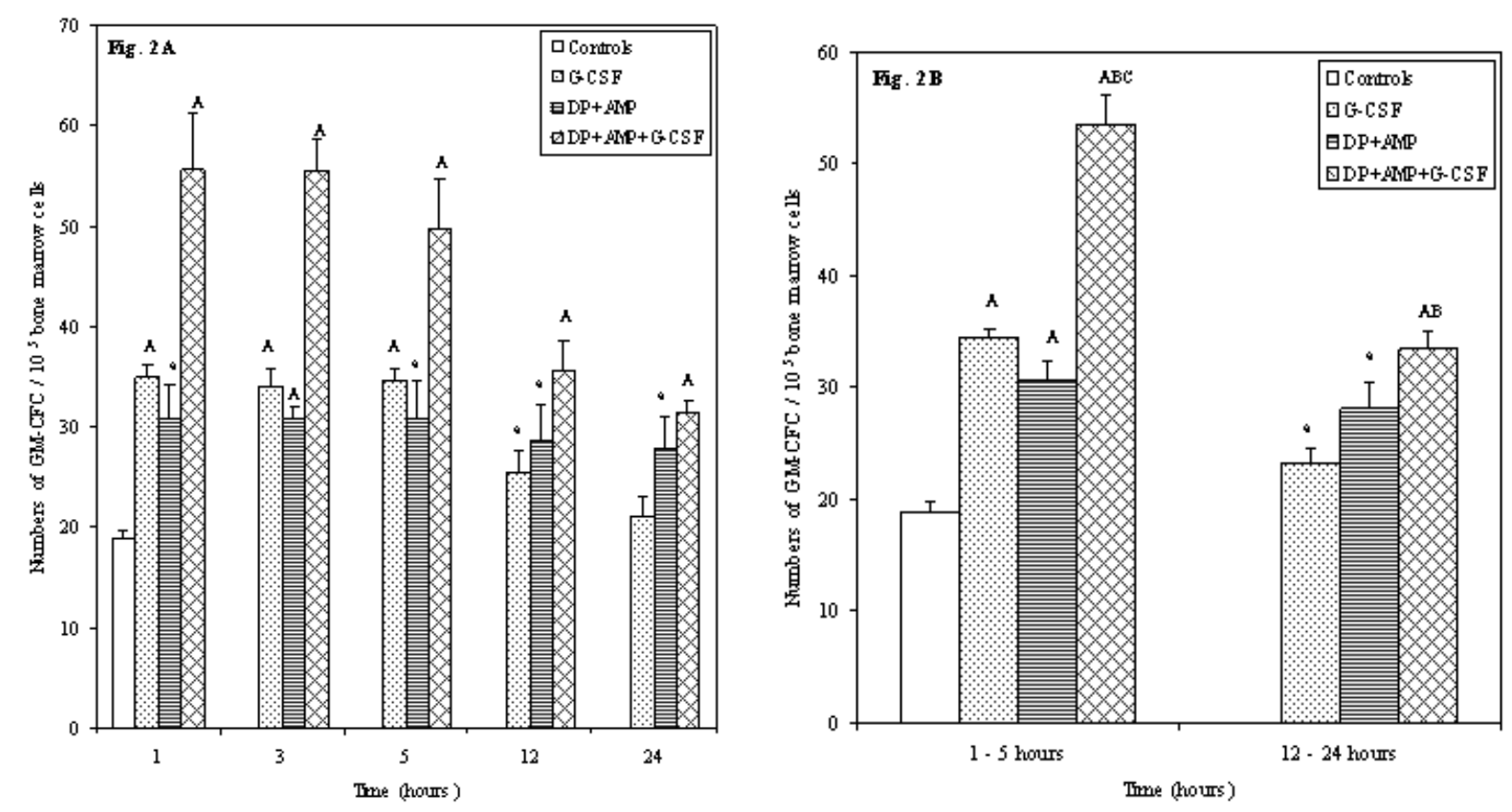

Fig. 2A, B. Numbers of GM-CFC per $10^{5}$ bone marrow cells in cultures treated with serum of mice administered G-CSF, DP+AMP or a combination of DP+AMP+G-CSF in a 4-d treatment regimen. Data are given as means \pm S.E.M. Controls - sera of control mice. Time time interval between the last injection of the drugs and serum sampling (Fig. $2 \mathrm{~A}$ - values in individual time intervals, Fig. 2B - values in grouped early and late intervals). Statistical significance: $A$ and $a, p<0.01$ and $p<0.05$, respectively, in comparison with controls. B, $\mathrm{p}<0.01$, in comparison with the cultures treated with serum of mice administered G-CSF alone. $\mathrm{C}, \mathrm{p}<0.01$, in comparison with the cultures treated with serum of mice administered DP+AMP.

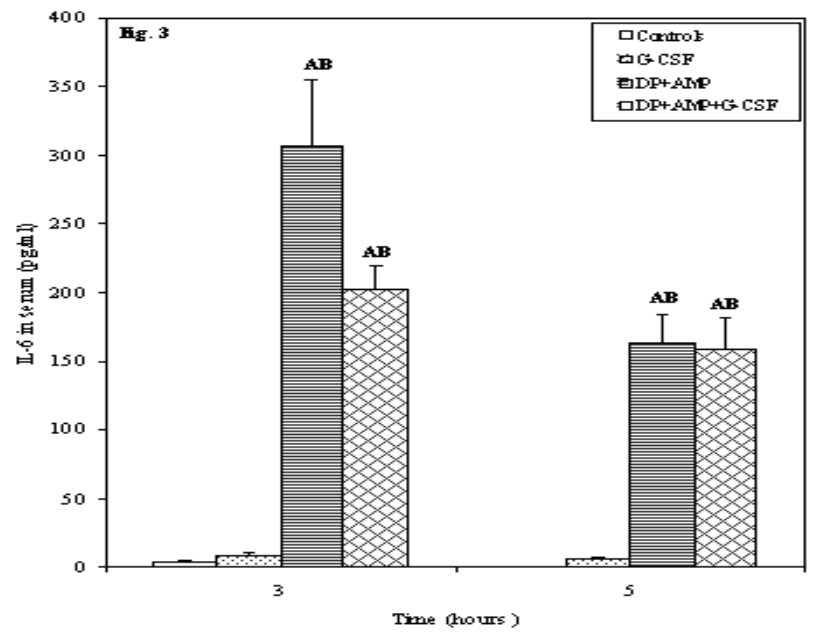

Fig. 3. IL-6 in sera of mice administered G-CSF, DP+AMP or a combination of DP+AMP+G-CSF in a single dose. Data are given as means \pm S.E.M. Controls - sera of control mice. Time - time interval between the last injection of the drugs and serum sampling. Statistical significance: $A, p<0.01$, in comparison with controls. $\mathrm{B}, \mathrm{p}<0.01$, in comparison with serum of mice administered G-CSF alone. Results represent data of two experiments.

\section{Discussion}

The results of the present experiments indicate that sera of mice administered DP+AMP and thus enhancing adenosine receptor-mediated actions are able to potentiate the production of GM-CFC in the cultures of normal bone marrow cells, i.e. that the sera exhibit CSA. Furthermore, it follows from our results that DP+AMP can act in cooperation with G-CSF, a granulopoiesisstimulating hematopoietic growth factor, in inducing the colony growth. These findings are consistent with results of studies performed previously in our laboratories, which showed that administration of DP+AMP stimulates hematopoiesis in myelosuppressed mice (Hofer et al. 1995, 2002). Moreover, the elevation of extracellular adenosine was found to mobilize significantly both GM-CFC and granulocytes into the peripheral blood after both single or repeated administration of DP+AMP (Hofer et al. 2003). It has also been shown that DP+AMP and G-CSF synergize to enhance granulopoiesis in normal mice (Pospíśil et al. 1995) and to increase hematopoietic recovery from myelosuppression resulting from exposure of mice to ionizing radiation and/or cytostatic drugs (Pospíšil et al. 1998, Hofer et al. 1999, 2001, Weiterová et al. 2000). It has been noted that these hematopoiesis-stimulating effects are pleiotropic and result from enhanced cycling of progenitor cells (Pospísil et al. 2001). The possibility of utilizing adenosine receptor signaling in enhancement of hematopoiesis has also been confirmed by experiments of Fishman et al. (2000) and Bar-Yehuda et al. (2002) demonstrating the 
curative effects of adenosine and an adenosine A3 receptor agonist on hematopoiesis in cyclophosphamidetreated mice.

In the present study, the effectiveness of sera of mice taken in early (1-5 h) and late time intervals (12-24 h) after administration of the tested drugs was investigated. Evaluating CSA in the early time intervals a few hours after administration of the tested drugs opens the question of whether CSA of the serum in the early time intervals is mediated by factors induced by the drugs in recipient's organism, or if simply the effects of these drugs still persisting in the serum are observed. Adenosine is short-lived in the organism. The data in humans show that the half-life of adenosine in plasma or whole blood is only a few seconds (Klabunde 1983, Möser et al. 1989). In our study, AMP was used instead of adenosine because its greater solubility in water allowed to achieve effective plasma concentrations without an excessive fluid load. It is known that AMP is rapidly metabolized extracellularly to adenosine via ecto5 -nucleotidase, an enzyme present in a variety of cells (Gordon et al. 1989). The half-life of degradation of adenosine nucleotides to adenosine in the extracellular space is again very short; adenosine becomes undetectable within tens of seconds (Shapiro et al. 1992, Meghji 1993, Dunwiddie et al. 1997). Moreover, the experiments examining the relation between adenosine production after administration of AMP to rats and increased blood flow suggested that AMP is rapidly transported to the active site for adenosine (Obata et al. 1996). As proposed in a study of kinetics of cell growth by Gualtieri et al. (1986), the addition of adenosine to long-term cultures results in similar effects as that observed with AMP. The data in literature thus provide evidence for rapid degradation of administered AMP and its metabolite adenosine. They seem to exclude the possibility that the effects of the drugs elevating extracellular adenosine on CSA of the serum observed in our experiments could be due to direct effects of adenosine persisting in the serum from the administered AMP till the time intervals of sampling. Therefore, the effects of extracellular adenosine may be supposed to be indirect, mediated by some cytokine(s) and/or growth factor(s) whose production is triggered by the adenosine receptor-mediated action. This holds for the action of DP+AMP alone, as well as for the effects of these drugs when given concomitantly with G-CSF. To obtain further support for this assumption, we added DP and AMP to the cultures of bone marrow cells in concentrations corresponding to levels of these drugs in the serum of mice at the time of administration. In comparison with controls, changes in the numbers of GM-CFC were not observed (data not given). Results of this additional experiment show that even when DP and AMP were present in the serum at the time of the sampling still in the same concentrations as were those attained immediately after the administration of the drugs, they were not able to induce the observed CSA effect alone. Less clear is the conclusion when evaluating the effects of G-CSF from this point of view. Data obtained in humans show the half-life of G-CSF is about 1-3 $\mathrm{h}$ (Akizawa et al. 1995, Kuwabara et al. 1996, Watari et al. 1997, Molineux 2004, Hernandez-Bernal et al. 2005). This implies that the serum of mice could probably contain sufficient concentrations of G-CSF capable of stimulating the growth of colonies from GM-CFC directly. However, it has to be noted that in our study aimed at the effects of extracellular adenosine, G-CSF served predominantly for the assessment of a possible enhancement of its granulopoietic effects by the drugs elevating extracellular adenosine, not for analyzing the mechanisms of its action.

The observations and considerations of the indirect effect of the drugs elevating extracellular adenosine brought us to search for the substance(s) responsible for the mediation of adenosine's membrane receptor action. In these experiments, increased IL-6 levels in the serum sampled at 3 or $5 \mathrm{~h}$ after single administration of DP+AMP were found. IL-6 is a pleiotropic cytokine, thought to play a key role in the regulation of hematopoiesis (Rodriguez et al. 2004, Nakamura et al. 2004). Although IL-6 alone does not stimulate in vitro proliferation of hematopoietic cells, it can synergize with other factors to induce proliferation of hematopoietic progenitor cells (Ikebuchi et al. 1988, Ogawa 1993, Patchen et al. 1993).

There is increasing evidence that adenosine signaling plays a role in the regulation of processes in the cytokine network. It was found that adenosine increased the release of IL-6 from human lung fibroblasts, rat peritoneal macrophages, adrenal and ovarian cells (Ritchie et al. 1997, Zhong et al. 2005) and augmented its production by monocytes stimulated with IL-1 $\beta$ or lipopolysacharides (Bouma et al. 1994, Song et al. 2005). It was reported that cAMP-dependent protein kinase is involved in the regulation of IL- 6 production and the increased cAMP level causes a significant potentiation of IL-6 release from monocytes, fibroblasts and LPS-treated macrophages (Vellenga et al. 1991, Martin and Dorf 1991, Tang et al. 1998). Recently it has been shown in 
studies with selective adenosine receptor agonists that adenosine receptor stimulation has a differential effect on the synthesis and release of IL- 6 and may induce its release in cell cultures (Straub et al. 2002, Forrest et al. 2005). Our findings thus provide new data about the role of cooperation between regulatory actions of adenosine signaling and those of IL-6. On the other hand, GM-CSF, a hematopoietic cytokine with a specific ability to stimulate the proliferation and differentiation of GMCFC, was not detected in our experiments in sera of mice given the drugs elevating extracellular adenosine. These results correspond to the findings from studies with drugs elevating cAMP level, suggesting a significant relationship between cAMP elevation and the inhibition of GM-CSF production (Shichijo et al. 1999, Seldon and Giembycz 2001, Lazzeri et al. 2001). In the present study, we limited our search for the mediators of the effects of extracellular adenosine to IL-6 and GM-CSF. However, it can also possible that other colonystimulating factors and/or cytokines are responsible for observed CSA in addition to IL-6 found in our experiments. This field is open for further studies.

A generally lower level of the values of
GM-CFC per $10^{5}$ bone marrow cells was observed in experiments evaluating repeated administration of the drugs. This finding may probably be explained by seasonal variations in GM-CFC numbers because the experiments testing single and repeated administration were performed in different periods of the year.

Our present results add new information on the mechanisms of hematopoiesis-stimulating effects of receptor-mediated action of extracellular adenosine. Furthermore, the observed prolonged effectiveness of the combination of DP+AMP manifested by the elevation of CSA up to 24 hours after a single administration of the drugs brings further support for the statement that the action of extracellular adenosine on hematopoiesis should not be neglected and that it might find a use in clinical practice.

\section{Acknowledgements}

The work was supported by the Grant Agency of the Czech Republic (grant no. 305/03/D050) and Grant Agency of the Academy of Sciences of the Czech Republic (grant VZ Z5004920).

\section{References}

ABBRACCHIO MP: P1 and P2 receptors in cell growth and differentiation. Drug Dev Res 39: 393-406, 1996.

AKIZAWA T, SHISHIDO K, KOSHIKAWA S: The effects and pharmacokinetics of rhG-CSF in patients with chronic renal failure. Artif Organs 19: 1251-1257, 1995.

BARRY CP, LIND SE: Adenosine-mediated killing of cultured epithelial cancer cells. Cancer Res 60: 1887-1894, 2000.

BAR-YEHUDA S, MADI L, BARAK D, MITTELMAN M, ARDON E, OCHAION A, COHN S, FISHMAN P: Agonists to the A3 adenosine receptor induce G-CSF production via NF-kB activation: a new class of myeloprotective agents. Exp Hematol 30: 1390-1398, 2002.

BOUMA MG, STAD RK, VAN DEN WILDENBERG FA, BUURMAN WA: Differential regulatory effects of adenosine on cytokine release by activated human monocytes. J Immunol 153: 4159-4168, 1994.

BOUMA MG, VAN DEN WILDENBERG FA, BUURMAN WA: Adenosine inhibits cytokine release and expression of adhesion molecules by activated human endothelial cells. Am J Physiol 270: C522-C529, 1996.

DUNWIDDIE TV, DIAO L, PROCTOR WR: Adenine nucleotides undergo rapid, quantitative conversion to adenosine in the extracellular space in rat hippocampus. $J$ Neurosci 17: 7673-7682, 1997.

FEDOROČKO P, EGYED A, VACEK A: Irradiation induces increased production of haemopoietic and proinflammatory cytokines in the mouse lung. Int J Radiat Biol 78: 305-313, 2002.

FISHMAN P, BAR-YEHUDA S, FARBSTEIN T, BARER F, OHANA G: Adenosine acts as a chemoprotective agent by stimulating G-CSF production: a role for A1 and A3 adenosine receptors. J Cell Physiol 183: 393-398, 2000.

FORREST CM, HARMAN G, MCMILLAN RB, STOY N, STONE TW, DARLINGTON LG: Modulation of cytokine release by purine receptors in patients with rheumatoid arthritis. Clin Exp Rheumatol 23: 89-92, 2005.

FREDHOLM BB, IJZERMAN AP, JACOBSON KA, KLOTZ KN, LINDEN J: Nomenclature and classification of adenosine receptors. International Union of Pharmacology XXV. Pharmacol Rev 53: 527-552, 2001. 
GORDON EL, PEARSON JD, DICKINSON ES, MOREAU D, SLAKEY LL: The hydrolysis of extracellular adenine nucleotides by arterial smooth muscle cells. Regulation of adenosine production at the cell surface. $J$ Biol Chem 264: 18986-18995, 1989.

GUALTIERI RJ, BERNE RM, MCGRATH HE, HUSTER WJ, QUESENBERRY PJ: Effect of adenine nucleotides on granulopoiesis and lithium-induced granulocytosis in long-term bone marrow cultures. Exp Hematol 14: 689$695,1986$.

HALAAS O, OLSEN WM, VEIBY OP, LOVHAUG D, SKJAK-BRAEK G, VIK R, ESPEVIK T: Mannuronan enhances survival of lethally irradiated mice and stimulates murine haematopoiesis in vitro. Scand J Immunol 46: 358-365, 1997.

HANLEY MB, NAPOLITANO LA, MCCUNE JM: Growth hormone-induced stimulation of multilineage human hematopoiesis. Stem Cells 23: 1170-1179, 2005.

HASKO G, KUHEL DG, CHEN JF, SCHWARZSCHILD MA, DEITCH EA, MABLEY JG, MARTON A. Adenosine inhibits IL-12 and TNF $\alpha$ production via adenosine A2a receptor-dependent and independent mechanisms. FASEB J 14: 2065-2074, 2000.

HERNANDEZ-BERNAL F, GARCIA-GARCIA I, GONZALEZ-DELGADO CA, VALENZUELA-SILVA C, SOTOHERNANDEZ R, DUCONGE J, CERVANTES-LLANO M, BLANCO-GARCES E, RODRIGUEZ V, GARCIA-VEGA Y, BELLO-RIVERO I, OLIVERA-RUANO L, LOPEZ-SAURA P: Bioequivalence of two recombinant granulocyte colony-stimulating factor formulations in healthy male volunteers. Biopharm Drug Dispos 26: 151-159, 2005.

HOFER M, POSPÍŠIL M, NETÍKOVÁ J, ZNOJIL V, VÁCHA J, HOLÁ J: Radioprotective efficacy of dipyridamole and AMP combination in fractionated radiation regimen, and its dependence on the time of administration of the drugs prior to irradiation. Physiol Res 44: 93-98, 1995.

HOFER M, POSPÍŠIL M, NETÍKOVÁ J, ZNOJIL V, VÁCHA J: Enhancement of haemopoietic spleen colony formation by drugs elevating extracellular adenosine: effects of repeated in vivo treatment. Physiol Res 46: 285-290, 1997.

HOFER M, POSPÍŠIL M, NETÍKOVÁ J, ZNOJIL V, VÁCHA J: Granulocyte colony-stimulating factor and drugs elevating extracellular adenosine act additively to enhance the hemopoietic spleen colony formation in irradiated mice. Physiol Res 48: 37-42, 1999.

HOFER M, POSPÍŠIL M, WEITEROVÁ L, ZNOJIL V, VÁCHA J, HOLÁ J, VACEK A, PIPALOVÁ I: Combination of drugs elevating extracellular adenosine with granulocyte colony-stimulating factor promotes granulopoietic recovery in the murine bone marrow after 5-fluorouracil treatment. Physiol Res 50: 521-524, 2001.

HOFER M, POSPÍŠIL M, ZNOJIL V, VACEK A, WEITEROVÁ L, HOLA J, VÁCHA J: Drugs elevating extracellular adenosine promote regeneration of haematopoietic progenitor cells in severely myelosuppressed mice: their comparison and joint effects with the granulocyte colony-stimulating factor. Eur J Haematol 68: 4-11, 2002.

HOFER M, VACEK A, POSPÍŠIL M, WEITEROVÁ L, HOLÁ J, ŠTREITOVÁ D, ZNOJIL V: Adenosine potentiates stimulatory effects on granulocyte-macrophage hematopoietic progenitor cells in vitro of IL-3 and SCF, but not those of G-CSF, GM-CSF and IL-11. Physiol Res 55: 591-596, 2006.

HOFER M, VACEK A, WEITEROVÁ L: Action of granulopoiesis-stimulating cytokines rhG-CSF, rhGM-CSF, and rmGM-CSF on murine hematopoietic progenitor cells for granulocytes and macrophages (GM-CFC). Physiol Res 54: 207-213, 2005.

HOFER M, WEITEROVÁ L, VACEK A, ZNOJIL V, POSPÍŠIL M, VÁCHA J: Elevation of extracellular adenosine mobilizes haematopoietic progenitor cells and granulocytes into peripheral blood and enhances the mobilizing effects of granulocyte colony-stimulating factor. Eur J Haematol 71: 204-210, 2003.

IKEBUCHI K, IHLE JN, HIRAI Y, WONG GG, CLARK SC, OGAWA M: Synergistic factors for stem cell proliferation: further studies of the target stem cells and the mechanism of stimulation by interleukin-1, interleukin-6, and granulocyte colony-stimulating factor. Blood 72: 2007-2014, 1988.

JACOBSON KA: Adenosine A3 receptors: novel ligands and paradoxical effects. Trends Pharmacol Sci 19: 184-191, 1998. 
KHALDOYANIDI S, KARAKHANOVA S, SLEEMAN J, HERRLICH P, PONTA H: CD44 variant-specific antibodies trigger hemopoiesis by selective release of cytokines from bone marrow macrophages. Blood 99 : 3955-3961, 2002.

KLABUNDE RE. Dipyridamole inhibition of adenosine metabolism in human blood. Eur J Pharmacol 93: 21-26, 1983.

KLOTZ KN: Adenosine receptors and their ligands. Naunyn-Schmiedeberg's Arch Pharmacol 362: 382-391, 2000.

KOHNO Y, SEI Y, KOSHIBA M, KIM HO, JACOBSON KA: Induction of apoptosis in HL-60 promyelocytic leukemia cells by adenosine A3 receptor agonists. Biochem Biophys Res Commun 219: 904-910, 1996.

KRONENWETT R, BUTTERWECK U, STEIDL U, KLISZEWSKI S, NEUMANN F, BORK S, BLANCO ED, ROES N, GRAF T, BRORS B, EILS R, MAERCKER C, KOBBE G, GATTERMANN N, HAAS R: Distinct molecular phenotype of malignant CD34+ hematopoietic stem and progenitor cells in chronic myelogenous leukemia. Oncogene 24: 5313-5324, 2005.

KUWABARA T, KOBAYASHI S, SUGIYAMA Y: Pharmacokinetics and pharmacodynamics of a recombinant human granulocyte colony-stimulating factor. Drug Metab Rev 28: 625-658, 1996.

LAZZERI N, BELVISI MG, PATEL HJ, YACOUB MH, CHUNG KF, MITCHELL JA: Effects of prostaglandin E 2 and cAMP elevating drugs on GM-CSF release by cultured human airway smooth muscle cells. Relevance to asthma therapy. Am J Respir Cell Mol Biol 24: 44-48, 2001.

LEBEDEV VG, MOROZ BB, DESHEVOI IUB, LYRSHCHIKOVA AV: The role of hematopoietic microenvironment in prodigiozan mechanism of action on postradiation recovery of hemopoiesis in long-term bone marrow cultures. Patol Fiziol Eksp Ter 3: 7-10, 2004.

MARTIN CA, DORF ME: Differential regulation of interleukin-6, macrophage inflammatory protein-1, and JE/MCP-1 cytokine expression in macrophage cell lines. Cell Immunol 135: 245-258, 1991.

MCWHINNEY CD, DUDLEY MW, BOWLIN TL, PEET NP, SCHOOK L, BRADSHAW M, DE M, BORCHERDING DR, EDWARDS CK: Activation of adenosine A3 receptors on macrophages inhibits tumor necrosis factor-alpha. Eur J Pharmacol 310: 209-216, 1996.

MEGHJI P: Storage, release, uptake, and inactivation of purines. Drug Dev Res 28: 214-219, 1993.

MOLINEUX G: The design and development of pegfilgrastim (PEG-rmetHuG-CSF, Neulasta). Curr Pharm Des 10: 1235-1244, 2004.

MOSER GH, SCHRADER J, DEUSSEN A: Turnover of adenosine in plasma of human and dog blood. Am J Physiol Cell Physiol 256: C799-C806, 1989.

MUJOOMDAR M, HOSKIN D, BLAY J: Adenosine stimulation of the proliferation of colorectal carcinoma cell lines. Roles of cell density and adenosine metabolism. Biochem Pharmacol 66: 1737-1747, 2003.

NAKAMURA K, KOURO T, KINCADE PW, MALYKHIN A, MAEDA K, COGGESHALL KM: Src homology 2containing 5-inositol phosphatase (SHIP) suppresses an early stage of lymphoid cell development through elevated interleukin-6 production by myeloid cells in bone marrow. J Exp Med 199: 243-254, 2004.

OBATA T, YAMANAKA Y, HIRATA T, UCHIDA Y: Role of adenosine in blood flow in the rat intestine. Res Commun Mol Pathol Pharmacol 92: 369-372, 1996.

OGAWA M: Differentiation and proliferation of hematopoietic stem cells. Blood 81: 2844-2853, 1993.

OHANA G, BAR-YEHUDA S, BARER F, FISHMAN P: Differential effect of adenosine on tumor and normal cell growth: focus of the A3 adenosine receptor. J Cell Physiol 186: 19-23, 2001.

PATCHEN ML, FISCHER R, MACVITTIE TJ: Effects of combined administration of interleukin-6 and granulocyte colony-stimulating factor on recovery from radiation-induced hemopoietic aplasia. Exp Hematol 21: 338-344, 1993.

POSPÍŠIL M, HOFER M, ZNOJIL V, VÁCHA J, NETÍKOVÁ J, HOLÁ J: Synergistic effect of granulocyte colonystimulating factor and drugs elevating extracellular adenosine on neutrophil production in mice. Blood 86: 3692-3697, 1995.

POSPÍŠIL M, HOFER M, ZNOJIL V, NETÍKOVÁ J, VÁCHA J, HOLÁ J, VACEK A: Granulocyte colonystimulating factor and drugs elevating extracellular adenosine synergize to enhance haematopoietic reconstitution in irradiated mice. Eur J Haematol 60: 172-180, 1998. 
POSPÍŠIL M, HOFER M, VACEK A, NETÍKOVÁ J, HOLÁ J, ZNOJIL V, WEITEROVÁ L: Drugs elevating extracellular adenosine enhance cell cycling of hematopoietic progenitor cells as inferred from the cytotoxic effects of 5-fluorouracil. Exp Hematol 29: 557-562, 2001.

POSPÍŠIL M, HOFER M, VACEK A, ZNOJIL V, PIPALOVÁ I: Effects of stable adenosine receptor agonists on bone marrow hematopoietic cells as inferred from the cytotoxic action of 5-fluorouracil. Physiol Res 53: 549-556, 2004.

RITCHIE PK, SPANGELO BL, KRZYMOWSKI DK, ROSSITER TB, KURTH E, JUDD AM: Adenosine increases interleukin 6 release and decreases tumour necrosis factor release from rat adrenal zona glomerulosa cells, ovarian cells, anterior pituitary cells, and peritoneal macrophages. Cytokine 9: 187-198, 1997.

RODRIGUEZ M DEL C, BERNAD A, ARACIL M: Interleukin-6 deficiency affects bone marrow stromal precursors, resulting in defective hematopoietic support. Blood 103: 3349-3354, 2004.

SCHULTE G, FREDHOLM BB: Signalling from adenosine receptors to mitogen-activated protein kinases. Cell Signal 15: 813-827, 2003.

SELDON PM, GIEMBYCZ MA: Suppression of granulocyte/macrophage colony-stimulating factor release from human monocytes by cyclic AMP-elevating drugs: role of interleukin-10. Br J Pharmacol 134: 58-67, 2001.

SHAPIRO MJ, JELLINEK M, PYRROS D, SUNDINE M, BAUE AE: Clearance and maintenance of blood nucleotide levels with adenosine triphosphate-magnesium chloride injection. Circ Shock 36: 62-67, 1992.

SHICHIJO M, INAGAKI N, KIMATA M, SERIZAWA I, SAITO H, NAGAI H: Role of cyclic 3',5'-adenosine monophosphate in the regulation of chemical mediator release and cytokine production from cultured human mast cells. J Allergy Clin Immunol 103: S421-S428, 1999.

SON CG, HAN SH, CHO JH, SHIN JW, CHO CH, LEE YW, CHO CK: Induction of hemopoiesis by saenghyuldan, a mixture of Ginseng radix, Paeoniae radix alba, and Hominis placenta extracts. Acta Pharmacol Sin 24: 120126, 2003.

SONG Z, URIARTE S, SAHOO R, CHEN T, BARVE S, HILL D, MCCLAIN C: S-adenosylmethionine (SAMe) modulates interleukin-10 and interleukin-6, but not TNF, production via the adenosine (A2) receptor. Biochim Biophys Acta 1743: 205-213, 2005.

STRAUB RH, PONGRATZ G, GUNZLER C, MICHNA A, BAIER S, KEES F, FALK W, SCHOLMERICH J: Immunoregulation of IL- 6 secretion by endogenous and exogenous adenosine and by exogenous purinergic agonists in splenic tissue slices. J Neuroimmunol 125: 73-81, 2002.

TALMADGE J, CHAVEZ J, JACOBS L, MUNGER C, CHINNAH T, CHOW JT, WILLIAMSON D, YATES K: Fractionation of Aloe vera L. inner gel, purification and molecular profiling of activity. Int Immunopharmacol 4: 1757-1773, 2004.

TANG Y, FENG Y, WANG X: Calcitonin gene-related peptide potentiates LPS-induced IL-6 release from mouse peritoneal macrophages. J Neuroimmunol 84: 207-212, 1998.

VACEK A, ROTKOVSKÁ D, BARTONÍČKOVÁ A: Radioprotection of hemopoiesis conferred by aqueous extract from chlorococcal algae (Ivastimul) administered to mice before irradiation. Exp Hematol 18: 234-237, 1990.

VACEK A, HOFER M, BARNET K, ČECH K, PEKÁREK J, SCHNEIDEROVÁ H: Positive effects of dialyzable leukocyte extract (DLE) on recovery of mouse haemopoiesis suppressed by ionizing radiation and on proliferation of haemopoietic progenitor cells in vitro. Int J Immunopharmacol 22: 623-634, 2000.

VACEK A, HOFER M, WEITEROVÁ L, HOFEROVÁ Z, PIPALOVÁ I, MAŠEK K: Hemopoiesis-stimulating action of adamantylamide dipeptide: kinetics of increase of GM-CFC in femur and co-stimulating activity of serum, role of bone marrow stromal cells. Immunopharmacol Immunotoxicol 23: 505-517, 2001.

VELLENGA E, VAN DER VINNE B, DE WOLF JT, HALIE MR: Simultaneous expression and regulation of G-CSF and IL-6 mRNA in adherent human monocytes and fibroblasts. Br J Haematol 78: 14-18, 1991.

WATARI K, OZAWA K, TAKAHASHI S, TOJO A, TANI K, KAMACHI S, ASANO S: Pharmacokinetic studies of intravenous glycosylated recombinant human granulocyte colony-stimulating factor in various hematological disorders: inverse correlation between the half-life and bone marrow myeloid cell pool. Int J Hematol 66: 5767, 1997. 
WEITEROVÁ L, HOFER M, POSPÍŠIL M, ZNOJIL V, VÁCHA J, VACEK A, PIPALOVÁ I: Influence of the joint treatment with granulocyte colony-stimulating factor and drugs elevating extracellular adenosine on erythropoietic recovery following 5-fluorouracil-induced haematotoxicity in mice. Eur J Haematol 65: 310$316,2000$.

ZHONG H, BELARDINELLI L, MAA T, ZENG D: Synergy between A2B adenosine receptors and hypoxia in activating human lung fibroblasts. Am J Respir Cell Mol Biol 32: 2-8, 2005.

\section{Corresponding author}

L. Weiterová, Institute of Biophysics, Academy of Sciences of the Czech Republic, Královopolská 135, 61265 Brno, Czech Republic. E-mail: weit@ibp.cz 